\title{
A study on the subjectivity of college students' participation in media education
}

\author{
Lee, Jei-Young \\ Professor, Dept. of Public \& Relation, Kwandong University, Korea \\ Park, Chang-Woo \\ Professor, Dept. of Social \& Welfare, Kwandong University, Korea \\ Kim, Ji-Eun \\ Professor, Dept. of English Education, Kwandong University, Korea
}

\begin{abstract}
The aim of this study is to investigate college students' opinion on participation in media education. The research question is as follows: first, what is the college students' perceptions who participated in media education? Second, what are the differences among the perceptions of college students who participated in media education? To answer these research questions, we used Qmethodology, which is more useful in organizing subjectivity types and opinions of students, both in explaining and sorting of data by characteristic and personal opinion. As a result, two types were found; type 1 is the active participation type that focuses on the active participation in media education as a productive tool and teaching method, as well as diminishing the current controls and restrictions on its use in education. On the other hand, type 2 is the growing adaptive type and is positive for the future development of media education in a transitional role, while they think that current media education for college students is not qualitative yet, a productive tool and the quality of the information message is lacking, and so on.
\end{abstract}

Keywords: Q-methodology, Subjectivity, Media education, Participation

\section{INTRODUCTION}

The reason that college students need media education is that the consumption of media is growing rapidly, as the amount of time modern students use media has increased. Today, the term 'media education' is not unfamiliar to students and educators; however, as little as five to six years ago, much explanation was needed regarding media education. Most people understood it as the educational uses of media, as in audio-visual education programs, or the term was vague in both curricular use and understanding. Nevertheless, in a relatively short time people's interest in media education has been aroused and the credit for its importance should go to the programs of civil organizations. Media education nowadays is an effective solution to diminishing misunderstandings of the media and its use in tertiary education; moreover, it is an approach that should be included in education for the twentyfirst century.

However, in our society, any discussion on media education still remains at the conceptual level, and has not advanced to argue its justification and necessity. Despite lengthy discussions, systematic preparation, or academic support,

\footnotetext{
* Corresponding author. E-mail : jylee1231@empas.com Manuscript received May 17, 2011 ; accepted Jun.20, 2011
}

specific action has not been forthcoming. Korean media education should now move out from the discussion of concepts and become practical and specific. In other words, the focus should be changed from 'what is media education' to 'how can media education be improved or implemented more effectively.' Before this, it is necessary that the social development aspects related to understandings of 'media education' be divided into stages, and the current stage of Korean media education, both structure and its participants, should be diagnosed.

When we regard education as a process of communication, we need to establish tools for media education that convey the message to learners. In this case, our educational tool is education itself; for example, two of the tools within media, movies and television, are educational mediums when used for the purpose of education. These tools will be known as 'television media' and 'movie media' in this study.

In the twentieth century the use of media in education has increased rapidly, accompanied by advances in technology. The swift creation and reproduction of messages is now possible in movies, slides, radio and television broadcasts. In recent media education, the Internet is highly esteemed and is no longer restricted by technology or location. The various unique features of media education that have been affected by advances in technology have become important. The current 
study aims to see the effects of participation factors of college students, in order to discover more effective participation behavior within media education. Until quite recently, the research into 'personal types'(or patterns) of student involvement in media education has been rare, with little evidence for both its effectiveness and the range of student understanding of its benefits, values, and uses. Various tools and media which can be used in the educational field have increased rapidly, accompanied by advances in science and technology. In addition, the creation and reproduction of various messages are possible by movie, slide, radio, television, or voice and video recordings. Lately, in new approaches to media education, computers and the Internet have become more prominent. With this in mind, enhancing the effectiveness of education by showing various unique features of media education becomes important.

To further clarify the aim of this study is to investigate college students' opinion on the participation in media education. This requires incorporation of a many-sided discussion of politics, economics, and cultural issues into future research. For the purposes of this study, we use Q-methodology, which is more discovery-laden, and generative of hypotheses; it is also more useful in organizing subjectivity types and opinions of students, both in explaining and sorting of data by characteristic and personal opinion. This also has application to categorizing types of involvement among the general public, and determining the subjectivity of their reactions. Previous efforts in determining characteristics and opinion relied on quantitative methodologies (R-methodology), using objective statistical analysis of the types of reception behavior of participants in media education.

Q-methodological analysis can be more productive when analyzing factors in the reception of college students and the general public, although this study is concerned with the former population. Hence, this study concerns itself with college students'image of media education and their reception behavior, categorized by type and subjective perceptions of student respondents. Rather than basing our conclusion on deductive hypotheses, this study is driven by a method that aims at determining the characteristics of reception behavior and establishing implications based on Q-research.

\section{LITERATURE REVIEW}

Media education in Korea has changed in response to our changing political situation. As such, media education has been focused on criticizing media to maintain democracy and political liberation. From the end of the 1970s to 1980s, several societal movement groups have conducted media education by 'monitoring' media to protect and prevent consumers from the negative influences of business media, particularly-in regard to sexual and violent content. Media education in Korea has been done as a civil movement, one conducted by civil organizations such as the Catholic Church or Korea women's associations, and the YMCA. Consequently, it has a short history and scant theoretical research. Even though Korea media education has focused on preventing consumers from a sex-promoting and violence-saturated media, since the end of 1990, education programs for the production and usage of media have gradually increased. Recently, arguments for media education in the various fields by such groups as teachers, parents, citizen groups, and related academic circles have increased. This has gradually become a social issue with the establishment of media centers, media management programs and other related organizations.

People give and take information, share opinions, and form their values though media. So whether we will obtain harm or profit depends on how the media is used. Hence, we need to discuss viewpoints on the direction of media education. The first view point is one that is based on a deep distrust of media and its history is extensive. The origin of this viewpoint is the book Culture and Environment $\underline{1}$ ) by D. Thompson and F. R. Leavis. They claimed that the negative influence of media could be reduced through education and suggested schools be responsible for this role. They suggested various examples from newspapers, magazines and advertisements that insisted schools should protect the cultural standards of the people. Therefore, media is regarded as kind of an enemy that education should counteract, and as such, this situation has been a characteristic of media education for a long time. Secondly, the view is that media is a popular art, and the role of media education is defensive, although with a negative stance towards the media similar to the viewpoint of Thompson and Leavis. Lastly, the view is that the media is a learning tool and a neutral carrier of knowledge. This point of view sees the media more positively and practically in that it claims media can provide people with information, and can usefully expand their experience. For example, the program 'Critical Television Viewing'2) of WNET/Thirteen, developed by USA Broadcasting Corporation, shows people can judge the content of the program and make a prudent selection. Allows people to judge the content..... The results of this program further suggest that people may use media both wisely and selectively. Their choices are based on their expectations and needs based on critical thinking skills. Their choices are based on their expectations and their needs are based on critical thinking/ Their choices are based on their expectations and needs that are derived from critical thinking skills. The content of these programs included, as a background, information on the TV programming process, financial aspects, advertising techniques, and the process of news selection. As an application to teaching methods, this suggests that participants are capable of 'contents analysis,' analyzing and evaluating TV programs; this view emphasizes the importance of the 'critical' viewer's opinion. This type of media education program is regarded as the 'achievement of goal' of Anderson $\underline{3}$ ) which claims that viewers use TV selectively for their needs.

In the aforementioned, we have examined the historical background related to basic direction and principles of media education. Such studies on media education provide a context for media education in terms of philosophy, education content, and education methodology. Moreover, studies in the transition and historical change of viewpoints on the role of media contribute to systematizing the future structure of media education. Based on this background, one can infer that an 
analysis of college students' participation in media education will be meaningful, as they constitute future users of media education. With that future in mind, this study has targeted university students' participation in media education, and considers this a significant and fruitful area of research.

\section{RESEARCH QUESTION AND METHOD}

The current study uses Q-methodology that can measure subjective behavior which tends to be ignored in survey-based research.1) This study investigates the characteristics of each type based on the analysis of the various interests, feelings and opinions on the participation in media education by college students. With that in mind, the research question is as follows: first, what are the college students' perceptions who participated in media education? With regard to this research question, the types of participation of media education of college students and the characteristics of each types and relation between the implication and the phenomena in the digital society are investigated. Secondly, what are the differences between the perceptions of college students who participated in-media education? For this research question, in contrast to the first research question, the similarities and differences of responses will be analyzed by type. A small number of respondents will be used to elucidate these similarities and differences determined by ranking of opinion and subjective response.

\subsection{Research Method}

In the research question mentioned above, in regards to reception behavior of college students participating in media education, is more effectively answered with Q-methodology. Q-methodology is based on the viewpoint of the respondent and it can explain the various types of responses with respect to the more subjective responses. When we consider that the previous R-methodology was not capable of measuring subjective reception behavior, because it is based on deduction rather than inductive implicative-laden conclusions, we expect that Q-methodology will make the analysis of the study results more meaningful.

In this study, Q-methodology will be applied to the sorting of statement cards that is based on the students' opinion and the researchers' perception on the topic. As a source for statement cards, a Q-concourse was developed based on newspaper articles, specifically Korean articles on media education, advertisements, and interviews; from this data a Q-statement was written and a P-sample selected. Following this, sorting was done to determine the Q-sort, which was then analyzed using a PC QUANL program.

\subsection{Research Design}

\subsubsection{Q-sample and P-sample}

The Q-sample for this research is composed from the statements of college students' participation in media education, in order to document their subjective opinions and values. A 74 Q-population (concourse) was selected based on the media related literature review described above, and interviews targeting the general public. As the next step, representative statements were chosen randomly and reduced in number to a final 27 statement samples for the purposes of this study. These statements include all opinion values and were written to have positive, neutral, and negative balance (see Figure 1). Since Qmethodology deals with intra-individual differences rather than inter-individual differences, it is not influenced by the number of the P-sample.6)In addition, since the methodology of a Qstudy does not infer the characteristics of the population sample from the sample, selecting of the P-sample is not governed by probabilistic sampling methods. Finally, in this research, 15 people were selected as the P-sample.

\subsubsection{Q-sorting and Data Analysis}

After the selection of the Q-sample and P-sample, Q-sorters who were selected as the P-sample were formed from within the Q-sample; here, this process is called Q-sorting. The goal of Q-sorting is to reveal an individual's attitudes regarding a complex issue or situation by having individuals sort a Qsample based on a fixed distribution pattern after reading the statements.8) In this research, the participants sorted the cards which have the statements into one of the three categories, 'agree with,' 'disagree with' or 'neutral with.' Then they were required to rank the 'agree with'in order from most agreement $(+4)$ to least agreement (-4), with neutral as (0). In addition, sorters were asked to explain their reasons for ranking by most agreement and least agreement. These rankings were coded on a scale of one to ten, with most agreement $(+4)$ as 9 , and most disagreement (-4) as 1 , as shown on Table 1 . Such scores were then coded by statement number, whether 1 or 9 in increments, and this data was analyzed using the QUANL program.

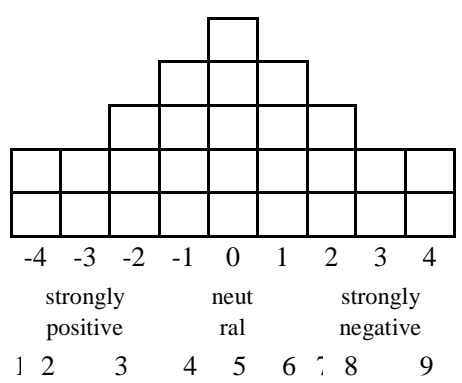

Fig. 1.Sample sorting board and record sheet

Table 1. Q-sort distribution

\begin{tabular}{|c|c|c|c|c|c|c|c|c|c|}
\hline & \multicolumn{9}{|c|}{ 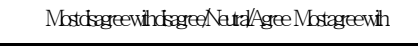 } \\
\hline rank & 4 & -3 & 2 & 1 & 0 & 1 & 2 & 3 & 4 \\
\hline score & 1 & 2 & 3 & 4 & 5 & 6 & 7 & 8 & 9 \\
\hline number of statement & 2 & 2 & 3 & 4 & 5 & 4 & 3 & 2 & 2 \\
\hline
\end{tabular}

Table 2. Z scores for each Q statement

\begin{tabular}{|c|c|}
\hline & $Z$ score \\
\hline Q-Statements & \begin{tabular}{|l|l|} 
Type1 & Type2 \\
$(\mathrm{N}=11)$ & $\mathrm{N}=4)$
\end{tabular} \\
\hline
\end{tabular}




\begin{tabular}{|c|c|c|}
\hline $\begin{array}{l}\text { 1. The education content of media education is still insufficient in tems of } \\
\text { theaspects of production. }\end{array}$ & -19 & 14 \\
\hline $\begin{array}{l}\text { 2. The participation in media education needs the samemulti-dimensional| } \\
\text { evaluation standards as regularclasses. }\end{array}$ & -14 & 12 \\
\hline $\begin{array}{l}\text { 3. Media education without voluntary participation of college students is } \\
\text { meaningless }\end{array}$ & -15 & 13 \\
\hline $\begin{array}{l}\text { 4. It is difficult to determine the educational effect using simple media-| } \\
\text { driven tools. }\end{array}$ & -14 & 06 \\
\hline 5. Media education for collegestudents is unreasonably lacking. & -16 & 12 \\
\hline $\begin{array}{l}\text { 6. College students' participation in the media education will affect thein } \\
\text { ethical andmoral values. }\end{array}$ & -10 & Q4 \\
\hline 7. Media education leads students intomulti-cultural involvement. & 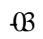 & -14 \\
\hline 8. Media education is notsufficient as an in-deptheducation. & 00 & $-\mathbb{R}$ \\
\hline $\begin{array}{l}\text { 9. The media education which does not consider the level of college } \\
\text { studentscannotbeeffective. }\end{array}$ & $-\infty$ & 11 \\
\hline $\begin{array}{l}\text { 10. The media education used in univessity education is not yet } \\
\text { praiseworthy. }\end{array}$ & 02 & 15 \\
\hline $\begin{array}{l}\text { 11. The future university media education should not be controlled or } \\
\text { restrictedinterms of expression. }\end{array}$ & 20 & 08 \\
\hline $\begin{array}{l}\text { 12. The content of the university's media education helps students } \\
\text { understandmedia well. }\end{array}$ & 06 & -16 \\
\hline $\begin{array}{l}\text { 13. The courses offered by media education departments can provide an } \\
\text { opportunity to understand key issues of politics, education, and culture. }\end{array}$ & 10 & -10 \\
\hline $\begin{array}{l}\text { 14. Media education courses should be provided with adequate } \\
\text { production facilities. }\end{array}$ & 13 & -16 \\
\hline $\begin{array}{l}\text { 15. The choice of the participation of media education up to the college } \\
\text { students themselves. }\end{array}$ & 13 & 01 \\
\hline $\begin{array}{l}\text { 16. A major purpose of University media education is to encourage } \\
\text { students tounderstand varied teaching styles. }\end{array}$ & 17 & -8 \\
\hline $\begin{array}{l}\text { 17. College media education should give the satisfaction to the general } \\
\text { public as well as tocollegestudents. }\end{array}$ & 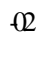 & -011 \\
\hline 18. Universitymedia education atpresent seems to lack creativity. & Q4 & Q \\
\hline $\begin{array}{l}\text { 19. The expansion of educational participation through the media can } \\
\text { become a facilitator for college students. However, it may cause the over- } \\
\text { simplification of a riculum. }\end{array}$ & 01 & -11 \\
\hline $\begin{array}{l}\text { 20. College students' interest in acquiring information is varied, but } \\
\text { questionablematerials should befiltered. }\end{array}$ & 01 & $\propto$ \\
\hline $\begin{array}{l}\text { 21. The course content structure of the university media education should } \\
\text { not be wholly responsivetostudents' desires. }\end{array}$ & 01 & $-\mathrm{AB}$ \\
\hline $\begin{array}{l}\text { 22. Immoral and unethical educational values broadcast through the } \\
\text { mediamaygivestudentsquestionablevalues and noms. }\end{array}$ & OR & -05 \\
\hline $\begin{array}{l}\text { 23. Recently, the problems apparent in approaches to media education } \\
\text { have often been addressed. }\end{array}$ & 01 & 16 \\
\hline $\begin{array}{l}\text { 24. Without the basic training of professors in charge of media education, } \\
\text { effective teaching is difficult. }\end{array}$ & 01 & -12 \\
\hline $\begin{array}{l}\text { 25. Developing dass content which is suited to colleges students who } \\
\text { participateinmedia education is needed. }\end{array}$ & $\Theta B$ & -01 \\
\hline $\begin{array}{l}\text { 26. The contents of the aurent media education has not been yet } \\
\text { populaized. }\end{array}$ & 05 & -08 \\
\hline $\begin{array}{l}\text { 27. Equally, participation the media education is not uniform or } \\
\text { widespread. }\end{array}$ & 09 & -08 \\
\hline
\end{tabular}

Table 3. Demographic characteristics of the samples and factor weight of each type.

\begin{tabular}{|c|c|c|c|c|c|}
\hline type & ID & gender & age & occupation & $\begin{array}{l}\text { factor } \\
\text { weight }\end{array}$ \\
\hline \multirow{5}{*}{$\begin{array}{c}\mathrm{I} \\
(\mathrm{N}=11)\end{array}$} & 1 & male & 21 & $\begin{array}{c}\text { university students, } \\
\text { sophomore }\end{array}$ & 2.7133 \\
\hline & 2 & male & 23 & university students, senior & 1.0348 \\
\hline & 3 & male & 24 & $\begin{array}{l}\text { university students, } \\
\text { sophomore }\end{array}$ & 1.4227 \\
\hline & 4 & male & 23 & university students, junior & 1.3188 \\
\hline & 5 & male & 28 & university students, senior & 1.6010 \\
\hline
\end{tabular}

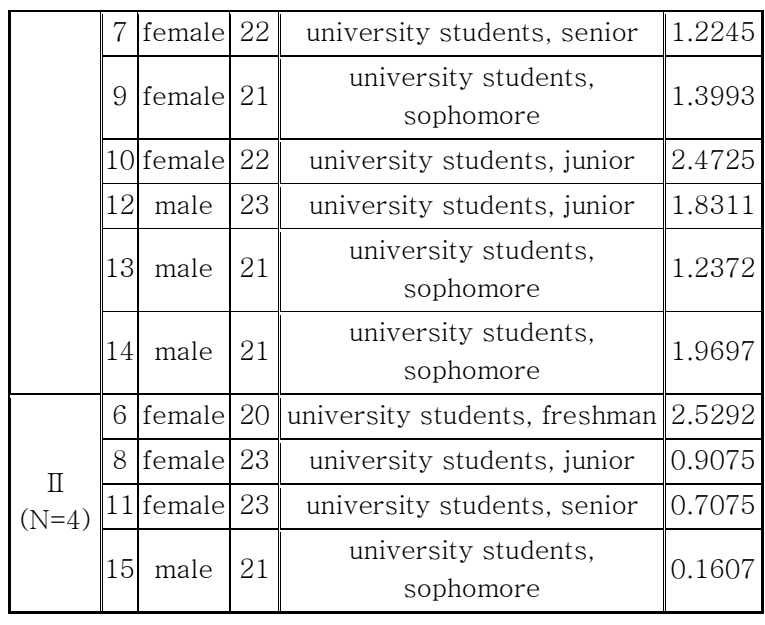

[Table 3] shows the demographic characteristics of the samples and factor weight of each type. In each type, the person who shows high factor weight is the person who can represent that type.

\section{RESULT AND DISCUSSION}

In order to see the subjectivity types of the university students' participation in media education, Q-factor analysis was conducted and two factors were found. As the result of the using QUANL program, 11 students were in type 1 and 4 students were in type 2 . Here, the number of students are meaningless and these two types explains about 65(0.6565)\% of total variance. Since the people whose factor weight is higher than 1.0 is 11 and 1 for each group, we can say that type 1 is the biggest factor. In addition, as we can see in table 4, the representative Eigen values are 8.7199, 1.1269 each.

Table 4. Eigen value and the variance

\begin{tabular}{|c|c|c|}
\hline Eigen value & 8.7199 & 1.1269 \\
\hline Variance & 0.5813 & 0.0751 \\
\hline Cumulative frequency & 0.5813 & 0.6565 \\
\hline
\end{tabular}

Table 5. The relation between types

\begin{tabular}{|c|c|c|}
\hline & Type 1 & Type 2 \\
\hline Type 1 & 1.000 & - \\
\hline Type 2 & -0.518 & 1.000 \\
\hline
\end{tabular}

[Table 5] shows the correlation coefficient between the types and it represents the similarities among types. Here, the correlation coefficient between type 1 and type 2 is -0.518 .

\subsection{Analysis of Type}

\subsubsection{Type 1(N=9): Active Participation Type}


Table 6. The statements that $\mathrm{Z}$ scores are higher than \pm 1.3 in type 1 .

\begin{tabular}{|c|l|c|}
\hline \multicolumn{1}{|c|}{ Qstatements } & Z-score \\
\hline agree & $\begin{array}{l}\text { 11. The future university media education should not be } \\
\text { controlled or restricted in terms of expression. } \\
\text { 16. A major purpose of University media education is to } \\
\text { encourage students to understand varied teaching styles. } \\
\text { 15. The choice of the participation of media education up to the } \\
\text { college students themselves. } \\
\text { 14. Media education courses should be provided with adequate } \\
\text { production facilities. }\end{array}$ & 1.98 \\
\hline dis- & $\begin{array}{l}\text { 2. The participation in media education needs the same multi- } \\
\text { dimensional evaluation standards as regular classes. } \\
\text { 4. It is difficult to determine the educational effect using simple } \\
\text { media-driven tools. } \\
\text { 3. Media education without voluntary participation of college } \\
\text { students is meaningless } \\
\text { 5. Media education for college students is unreasonably lacking. } \\
\text { 1. The education content of media education is still insufficient } \\
\text { in terms of the aspects of production. }\end{array}$ & -1.33 \\
\hline
\end{tabular}

As you can see in [table 6], the type 1 is the active participation type that focuses on the active participation in media as a productive tool and teaching method, as well as diminishing current control and restriction. Especially, the statement 11 in the "agree with" statement and statement 1 in "disagree with" statement show the characteristics of this type the best.

\subsubsection{Type $2(\mathrm{~N}=4)$ : Growing Adaptation Type}

Table 7. The statements that $\mathrm{Z}$ scores are higher than \pm 1.3 in type 2.

\begin{tabular}{|c|c|c|}
\hline \multicolumn{2}{|r|}{ Qstatements } & $\mathbf{Z}$ \\
\hline agree & $\begin{array}{l}\text { 23.Recently, theproblemsapparentinapproadnestomediaeducationhave } \\
\text { oftenbeenaddressed. } \\
\text { 10. The media education used in univesity education is not yet } \\
\text { praisewarthy. } \\
\text { 1. The education content of media education is sill insufficient in tems of } \\
\text { theaspedsofproduction. } \\
\text { 3. Media education without voluntary participation of college sudents is } \\
\text { meaningless. }\end{array}$ & $\begin{array}{l}1.64 \\
1.55 \\
1.44\end{array}$ \\
\hline $\begin{array}{l}\text { dis- } \\
\text { agree }\end{array}$ & $\begin{array}{l}\text { 7.Mediaeducationleadssudentsintomulti-alturalinvolvement. } \\
\text { 12. The content of the universitys media education helps sudents } \\
\text { undestandmediawell. } \\
\text { 14.Mediaeducation courses should beprovided with adequateproduction } \\
\text { facilities. }\end{array}$ & $\begin{array}{l}-1.56 \\
-1.62\end{array}$ \\
\hline
\end{tabular}

[Table 7] shows that the "type 2" is the "growing adaptive type." Type 2 is positive on the future development of media education in a transitional role, while they think that the current media education for college students is not qualitative enough as a productive tool and the quality of its information message, and so on*. Especially, the statement 23 in the "agree with" statement and statement 14 in "disagree with" statement show the characteristics of this type the best.

\subsection{Analysis of the differences between two types}

In the type difference analysis, the differences between the two types are explained in table 8 ? by comparing two types in terms of "agree with" and "disagree with" opinions. Here, the higher "difference" value means the statement is closer to each type.

Table 8. Item Descriptions And Descending Array Of Differences Between Type 1, 2

\begin{tabular}{|c|c|c|c|}
\hline \multirow[b]{2}{*}{ ITEM DESCRIPTIONS } & \multicolumn{2}{|c|}{ Z-SCORES } & \multirow[b]{2}{*}{ Diff. } \\
\hline & $\begin{array}{c}\text { TYPE } \\
1\end{array}$ & \begin{tabular}{|c|} 
TYPE \\
2
\end{tabular} & \\
\hline $\begin{array}{l}\text { 14. Media education courses should be } \\
\text { provided with adequate production facilities. }\end{array}$ & 1.319 & 1.625 & 2.944 \\
\hline $\begin{array}{l}\text { 16. A major purpose of University media } \\
\text { education is to encourage students to } \\
\text { understand varied teaching styles. }\end{array}$ & 1.743 & -0.777 & 2.520 \\
\hline $\begin{array}{l}\text { 12. The content of the university's media } \\
\text { education helps students understand media } \\
\text { well. }\end{array}$ & 0.595 & -1.559 & 2.154 \\
\hline $\begin{array}{l}\text { 13. The courses offered by media education } \\
\text { departments can provide an opportunity to } \\
\text { understand key issues of politics, education, } \\
\text { and culture. }\end{array}$ & 0.951 & -1.012 & 1.963 \\
\hline $\begin{array}{l}\text { 27. Equally, participation the media } \\
\text { education is not uniform or widespread. }\end{array}$ & 0.883 & -0.828 & 1.710 \\
\hline $\begin{array}{l}\text { 26. The co } \\
\text { education has }\end{array}$ & 0.543 & -0.767 & 1.310 \\
\hline $\begin{array}{l}\text { 15. The choice of the participation of media } \\
\text { education up to the college students } \\
\text { themselves. }\end{array}$ & 1.332 & 0.051 & 1.281 \\
\hline $\begin{array}{l}\text { 11. The future university media education } \\
\text { should not be controlled or restricted in } \\
\text { terms of expression. }\end{array}$ & 1.975 & 0.762 & 1.213 \\
\hline $\begin{array}{l}\text { 7. Media education leads students into } \\
\text { multi-cultural involvement. }\end{array}$ & -0.304 & -1.385 & 1.082 \\
\hline $\begin{array}{l}\text { 24. Without the basic training of professors } \\
\text { in charge of media education, effective } \\
\text { teaching is difficult. }\end{array}$ & -0.146 & -1.200 & 1.054 \\
\hline $\begin{array}{l}\text { cation used in university } \\
\text { praiseworthy. }\end{array}$ & 185 & 548 & .362 \\
\hline $\begin{array}{l}\text { 6. College students' participation in the } \\
\text { media education will affect their ethical and } \\
\text { moral values. }\end{array}$ & -0.955 & 0.414 & -1.369 \\
\hline $\begin{array}{l}\text { 23. Recently, the problems apparent in } \\
\text { approaches to media education have often } \\
\text { been addressed. }\end{array}$ & 0.119 & 1.636 & -1.517 \\
\hline $\begin{array}{l}\text { 9. The media education which does not } \\
\text { consider the level of college students cannot } \\
\text { be effective. }\end{array}$ & -0.658 & 1.055 & -1.713 \\
\hline $\begin{array}{l}\text { 4. It is difficult to determine the educational } \\
\text { effect using simple media-driven tools. }\end{array}$ & -1.434 & 644 & -2.078 \\
\hline $\begin{array}{l}\text { 2. The participation in media education } \\
\text { needs the same multi-dimensional evaluation } \\
\text { standards as regular classes. }\end{array}$ & -1.419 & 1.156 & -2.575 \\
\hline $\begin{array}{l}\text { 3. Media education without voluntary } \\
\text { participation of college students is } \\
\text { meaningless }\end{array}$ & -1.461 & 1.344 & -2.805 \\
\hline 5. Media education for college students is & -1.609 & 1.205 & -2.814 \\
\hline
\end{tabular}


unreasonably lacking.

\begin{tabular}{l|l|l|l} 
1. The education content of media education & -1.886 & 1.436 & -3.321
\end{tabular}

is still insufficient in terms of the aspects of production.

(* Differences $= \pm 1.000)$

As you can view in the table above, there is a clear difference between type 1 (Active Participation Type) and type 2 (Growing Adaptation Type) in terms of two statements; the statement 14; "Media education courses should provide-adequate production conditions" (Differences $=2.944$ ) and Statement 1. "The education content through media is still insufficient in terms of the aspect of production" (Differences = -3.321)." In terms of the statement 14 , two types show the clear positive difference, while they show the clear negative difference on statement 1 .

\subsection{Analysis of the Consensus Items}

Table 9. Consensus Items of each type

\begin{tabular}{|c|c|}
\hline QStatements & $\begin{array}{c}\mathrm{Z} \\
\text { score }\end{array}$ \\
\hline $\begin{array}{l}\text { 18. Universitymediaeducation atpresent seems to lack creativity. } \\
\text { 20. College students' interest in acquiring information is varied, but questionable } \\
\text { materials should befiltered. }\end{array}$ & \begin{tabular}{|l|}
0.31 \\
0.08
\end{tabular} \\
\hline 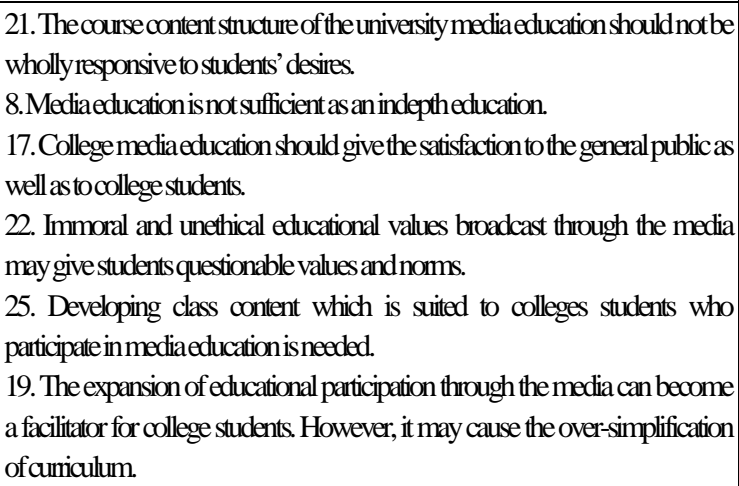 & $\begin{array}{l}-0.09 \\
-0.12 \\
-0.14 \\
-0.14 \\
-0.21 \\
-0.62\end{array}$ \\
\hline
\end{tabular}

The Q statements in consensus are two types totaling 8: 6 "disagree with" and 2 "agree with." Based on the analysis of thus consensus, we can conclude that the most subjects want a more various and creative media education than the current one.

\section{CONCLUSION AND IMPLICATION}

In this study, the Q-methodology was used to see the subjectivity on the university students' participation in media education. As a result, type $1(\mathrm{~N}=9)$ is the active participation type that focuses on the active participation in media education as a productive tool and teaching method, as well as diminishing the current controls and restriction on its use in education. Especially, statement 11 in the "agree with" statement, and statement 1 in "disagree with" statement show the characteristics of this type the best. On the other hand, type $2(\mathrm{~N}=4)$ is positive for the future development of media education in a transitional role, while they think that the current media education for the college students is not yet qualitative enough as a productive tool and the quality of the information message is lacking, and so on. Likewise, statement 23 in the "agree with" statement, and statement 14 in "disagree with" statement show the characteristics of this type the best. Q qualitative methodology (methods of measurement of subjectivity) was used rather than $\mathrm{R}$ methodology (questionnaire surveys and content analysis), which was usually used as the research method (Brown, 58-178). Therefore, this study can uncover the subjectivity of student responses, and the result shows only the types on the reception behavior in their participation with media education. Even though the differences between types were analyzed and the specific causes of the differences were found, there is a limitation in finding the most suitable type for reception behavior in the participation of media education at the tertiary level. It is expected that more specific and systematic research following the same lines will be necessary to evaluate and assess the effects of decision making related to the participation of college students in-media education.

\section{REFERENCES}

[1] J. Anderson, "Television literacy and the critical viewers", in J. Bryant and D.R. Anderson(ed.), Children's Understanding of Television, New York : Academic Press, 1988, pp.297-330.

[2] WNET/Thirteen, Critical Television Viewing : Teacher's annotated edition, New York : Cambridge, 1980.

[3] W. Stephenson, The Study of Behavior : Q-Technique and Its Methodology. Chicago, IL : University of Chicago Press, 1954, pp.14-27.

[4] DES, A Language for Life. The Bullock Report, London : HMSO, 1975.

[5] S. R. Brown, Political Subjectivity. New Haven, Mass. : Yale Univ. Press, 1980, pp.158-178.

[6] F. R. Leavis, \& D. Thompson, Culture and Environment, London : Chatto \& Windus, 1933.

[7] D. H. Sunwoo, "Study on consumer behavior by Qmethodology". Advertising study, summer(11). KOBACO. 1991, p.7.

[8] S. J. Simmon, "Health: A Concept Analysis". Int. J. Nurs. Study 26(2), 1989, pp.155-161.

[9] W. Stephenson, "Consciousness Out-Subjectivity". In, The Psychological Record, 1968, p.18.

[10] H. K. Kim, "Understanding of Q methodology for subjectivity study". a collection of learned papers in the science of nursing, 6(1), 1992, pp.1-11.

[11] H. K. Kim, "Exploration of science spirit of Qmethodology” <media Hakbo> 13. Hanyang University Media Culture Research center, 1993, pp.5-44.

[12] H. K. Kim, "Understanding and application of Qmethodology". Segang University Media Culture Research center. 45, 1990, pp.5-11. 


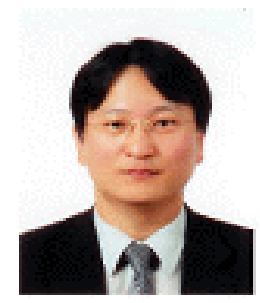

\section{Lee, Jei-Young}

He received Ph.D., in HUFS(Hankuk University of Foreign Studies), Korea, in 2005. Since then, he has been with main researcher, Media Future Institute, Korea for 2.5 years. His main research interests include media-contents and advertisingimage-policy. At present, he is a professor in Advertising \& Public relation Dept. of Kwandong Univ., Korea.

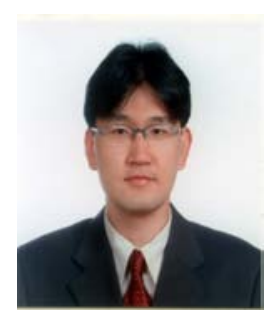

Univ., Korea.

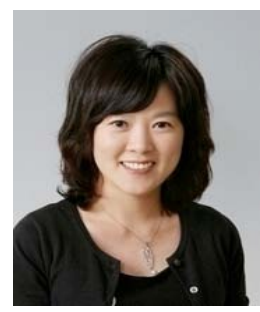

\section{Park, Chang-Woo}

He received Ph.D., in Baek-Seok, Korea, in 2007. Since then, he has been with main researcher, Holt Family Welfare Institute, Korea for 6 years. His main research interests include Christian welfare and Community Organization. Presently, he is a professor of Kwandong

\section{Kim, Ji-Eun}

She received her Ph.D. in Linguistics at the University of Texas(Arlington), USA in 2004. She was a professor of Brookhaven College, USA and Defense Language Institute, USA. Currently, she is a professor of Kwandong University, Korea. Her research interests include English education and Phonetics. 